\title{
Deoxyribonucleic Acid Reassociation in the Taxonomy of Enteric Bacteria
}

\author{
DON J. BRENNER
}

Walter Reed Army Institute of Research, Washington, D. C. 20012

\begin{abstract}
A brief summary of the deoxyribonucleic acid (DNA) relatedness of members of the family Enterobacteriaceae is presented. The application and utility of DNA relatedness to bacterial taxonomy are discussed in order to stimulate greater awareness and use of this technique. Applications include: (i) the recognition of new taxa; (ii) the identification of grossly atypical strains in a taxon; (iii) the classification of poorly studied groups of organisms; and (iv) changes in existing classifications. Also discussed are the identification and differentiation of bacteria in the clinical laboratory. Guidelines for the molecular definition of species are presented.
\end{abstract}

Deoxyribonucleic acid (DNA) hybridization techniques are about 10 years old. They have been more readily accepted by the geneticist and the molecular biologist than by the bacterial taxonomist. The reticence shown by many taxonomists is due, in part, to seemingly contradictory results in some hybridization studies, to a lack of appreciation for the parameters involved in reaction specificity, and to the seeming absence of a "hard" value for species relatedness. Furthermore, there have been no rules for meaningful relatedness at any taxonomic level, be it family, tribe, genus, or species.

One purpose of this talk (presented at the Annual Meeting of the American Society for Microbiology, 1973) is to dispel any doubts about the validity and utility of DNA reassociation as a taxonomic method. I hope to illustrate the use of different experimental criteria for different taxonomic purposes and to discuss the interpretation of DNA-relatedness data. This discussion will be restricted to DNA-DNA reassociation, but it should be noted that most of these techniques are equally applicable to reassociation of DNA with complementary ribonucleic acid (RNA).

Bacterial DNAs are macromolecules (molecular weight of $10^{9}$ to $4 \times 10^{9}$ ) composed of two strands of covalently linked deoxyribonucleotide bases, adenine (A), thymine ( $T$ ), cytosine $(C)$, and guanine $(G)$. The DNA strands are held together by hydrogen bonds formed specifically only between $A$ and $T$ and between $G$ and $C$. $A-T$ and G-C are termed complementary base pairs. Due to the specificity of base pair formation, the base sequence of one DNA strand determines the sequence of the other, or complementary, strand. For instance, if the sequence of one strand is A-G-C-T-G-A, we know that the other strand must have the complementary sequence T-C-G-A-C-T. The two strands of DNA may be separated by heating or by alkali. Once separated, the strands can specifically reassociate.

These two properties, specificity of base pairing and reversible separation of strands, make DNA reassociation a powerful and sensitive probe with which to assess genetic relatedness between organisms. In most procedures DNA from one or more organisms is labeled (this is termed "reference" DNA) and then reassociated with an excess of unlabeled DNA from the same organism and from other organisms of interest. The reassociated (also termed duplexed, related, bound, or hybridized) DNA is separated from unreacted DNA and quantitative relatedness is determined by normalizing the extent of heterologous DNA reassociation to the extent of reassociation observed in the homologous reaction.

Hybridization methods. The hybridization methods currently in vogue are the nitrocellulose filter method (8) and the hydroxyapatite (HA) method $(1,6,21)$. Each method has certain technical advantages. There are several modifications of each method, and each has its adherents. The important fact is that, used properly, these methods yield comparable data, and each is reproducible to within about $5 \%$. A third method assesses relatedness spectrophotometrically by measuring the rate of renaturation of DNA mixtures. This method has the substantial advantage of not requiring labeled 
DNA $(8,23)$. In our hands, this method is not as accurate as the others; however, it has been valuable in distinguishing qualitatively between closely related and distantly related organisms.

Parameters affecting DNA reassociation. Regardless of the method used, an understanding of the parameters that affect DNA reassociation is essential to obtain meaningful results. For most applications, the size of DNA fragments and the ionic strength of the incubation medium may be held at any constant value within a fairly wide range without significantly affecting the results. Other conditions must be varied carefully with the G-C content of the organism and the type of information one desires.

Highly purified DNA preparations are essential. Contaminating protein or RNA, or both, will result in falsely high or falsely low relatedness values depending upon whether the contaminants act like single-stranded or doublestranded DNA in the assay system. Pure DNA is especially critical in studies where specific portions of the genome are of interest.

DNA reassociates optimally at temperatures 25 to $30 \mathrm{C}$ below that required for denaturation $(16,18)$. Since G-C base pairs exhibit greater thermal stability than do A-T base pairs (17), the optimal reassociation temperature varies with the percent $\mathrm{G}+\mathrm{C}$ in a given DNA. Incubation temperatures significantly below the optimum allow reassociation of distantly related and unrelated sequences $(13,19)$. Alternatively, incubation temperatures significantly above the optimum allow only highly complementary sequences to reassociate $(2,13)$. Therefore, optimal temperature for reassociation of DNA with $50 \% \mathrm{G}+\mathrm{C}$ is restrictive for DNA with $30 \% \mathrm{G}+\mathrm{C}$ and favors nonspecific binding in DNA with $70 \% \mathrm{G}+\mathrm{C}$.
Some causes of confusion in the interpretation of DNA heteroduplex data are the use of insufficiently pure DNA, incubation temperatures resulting in nonspecific binding, and assay techniques that preclude detection of all but essentially identical nucleotide sequences. There has been both a desire and a tendency to equate the degree of heterologous duplex formation, or DNA binding, with the degree of homology between organisms. In other words, it was often assumed that $60 \%$ DNA binding indicated the presence of $60 \%$ identical stretches of DNA and $40 \%$ completely unrelated DNA. Finally, a good deal of confusion and consternation arose from the fact that, in many instances, the relatedness between many organisms varies as much as fivefold or more depending upon the incubation temperature.

These sources of confusion are minimized or totally eliminated when one realizes what types of information are obtainable from DNA reassociation and how to shift the experimental parameters to answer specific taxonomic questions. Table 1 illustrates the effect of incubation temperature on DNA duplex formation between labeled Escherichia coli DNA and unlabeled DNA from various organisms. It is evident that increased incubation temperature has little effect on the reaction between DNAs from the highly related organisms Escherichia coli and Shigella boydii. In all other reactions, the binding at $66 \mathrm{C}$ is decreased almost twofold compared with the binding observed at the optimal incubation temperature, $60 \mathrm{C}$. At $75 \mathrm{C}$, binding is four- to sixfold lower than that at 60 C.

Why does binding vary so little in the $E$. coli-S. boydii reaction and change so markedly in reactions with organisms less closely related to $E$. coli? Which, if any, of these values is

TABLE 1. Effect of incubation temperature on DNA duplex formation ${ }^{a}$

\begin{tabular}{|c|c|c|c|}
\hline \multirow[b]{2}{*}{ DNA reaction ${ }^{b}$} & \multicolumn{3}{|c|}{ Relative binding (\%) at } \\
\hline & $60 \mathrm{C}$ & $66-67 \mathrm{C}$ & $75 \mathrm{C}$ \\
\hline Escherichia coli/E. coli & 100 & 100 & 100 \\
\hline E. coli/Shigella boydii. & 89 & 87 & 85 \\
\hline E. coli/Salmonella typhimurium & 45 & 28 & 11 \\
\hline E. coli/Enterobacter aerogenes ..... & 37 & 23 & 8 \\
\hline E. coli/Enterobacter hafniae ............ & 21 & 11 & 4 \\
\hline E. coli/Proteus mirabilis . . . . . . . . . . & 6 & & 1 \\
\hline
\end{tabular}

${ }^{a}$ Reactions were carried out in $0.14 \mathrm{M}$ phosphate buffer and assayed on hydroxyapatite (HA). In $0.14 \mathrm{M}$ phosphate buffer, single-stranded DNA elutes from HA and reassociated DNA binds to HA. Double-stranded DNA was eluted from HA by using $0.4 \mathrm{M}$ phosphate buffer. Experimental details are similar to those described in references 4 and 5 .

$b$ Organism on left $(E$. coli) was source of labeled DNA. 
correct? The answers to these questions become evident when one examines the thermal stability of these reaction products. To do this one exposes heterologous DNA duplexes bound to $\mathrm{HA}$ to a series of elutions at increasing temperatures. As the temperature exceeds the $T_{m(e)}$ (temperature at which one-half of the DNA bound to HA is denatured) of a given stability class of heteroduplex DNA, the frag- ments are eluted from $\mathrm{HA}$ as single-stranded DNA. Typical thermal-elution profiles are shown in Fig. 1. Thermal-elution profiles obtained from homologous $E$. coli reactions carried out at 60 and $75 \mathrm{C}$ exhibit a normal distribution pattern and an elution midpoint at about 90 C. Duplexes formed between $E$. coli and a closely related strain of Shigella dysenteriae at either incubation temperature are
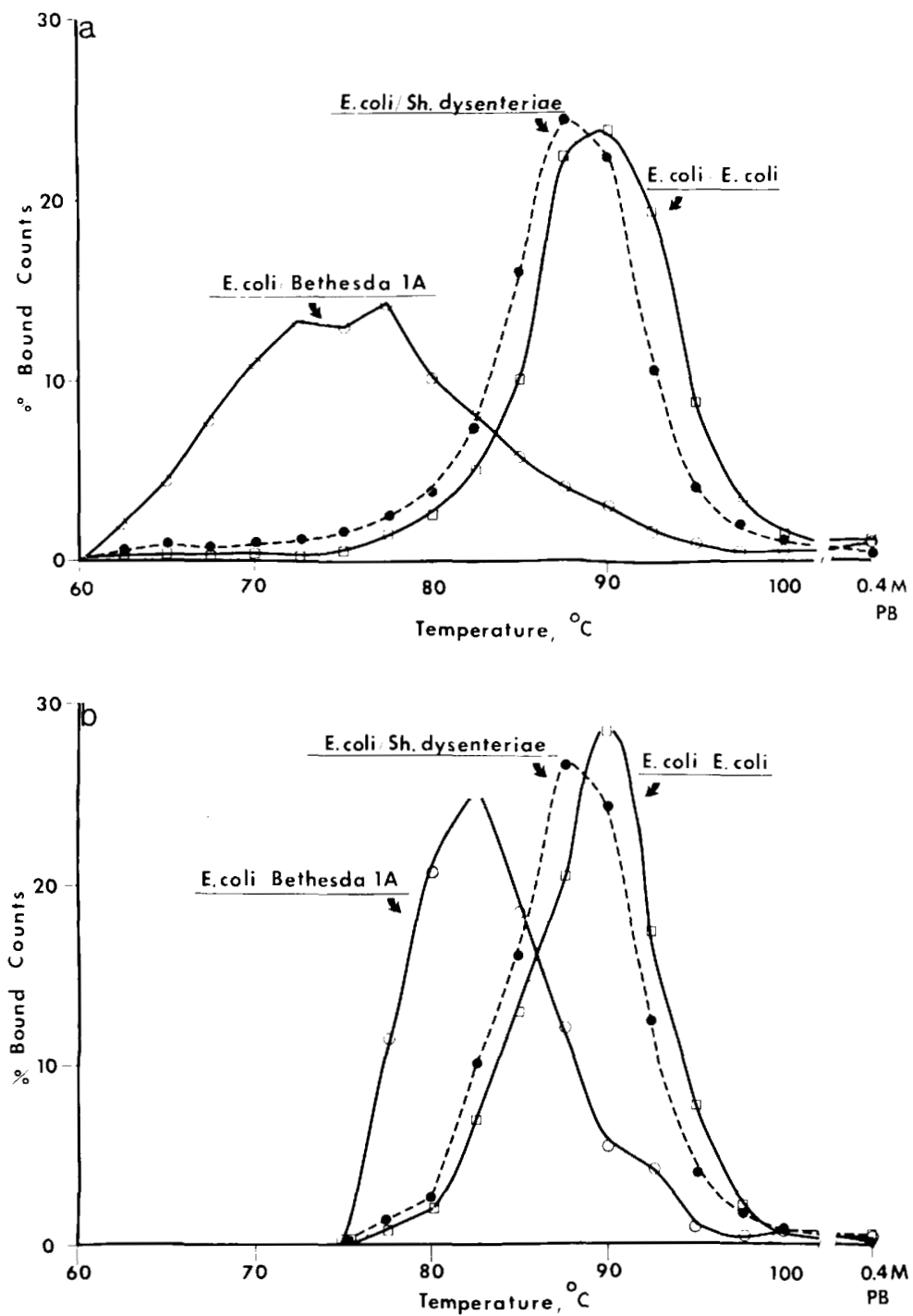

FIG. 1. Thermal-elution profiles of enterobacterial DNA duplexes. Labeled Escherichia coli DNA was incubated with unlabeled DNA from E. coli, Shigella dysenteriae, and Bethesda (Citrobacter freundii) strain $1 A$. Incubations were carried out in $0.14 \mathrm{M}$ phosphate buffer, and the solutions were added to hydroxapatite (HA) equilibrated with $0.14 \mathrm{M}$ phosphate buffer and held at the temperature used for incubation. Reassociated duplexes were eluted from $H A$ in a series of washes with $0.14 \mathrm{M}$ phosphate buffer at increasing $2.5 \mathrm{C}$ temperature increments to $100 \mathrm{C}$. The $H A$ was then washed with $0.4 \mathrm{M}$ phosphate buffer to insure that all DNA had been eluted. a, $60 \mathrm{C}$ incubation; b, $75 \mathrm{C}$ incubation. Taken from Brenner and Falkow, 1972. 
slightly less stable than the homologous $E$. coli duplexes. The $60 \mathrm{C}$ reaction product of $E$. coli and Bethesda 1A DNAs is obviously significantly less stable than the other reaction products. At $75 \mathrm{C}$, less than $10 \%$ of $E$. coli DNA can reassociate with DNA from Bethesda $1 \mathrm{~A}$ compared with $45 \%$ at $60 \mathrm{C}$. Those duplexes that are formed at the higher incubation temperature, although still significantly less stable than homologous duplexes, show markedly increased stability.

The increased stability of duplexes formed at $75 \mathrm{C}$, coupled with decreased heteroduplex formation, is due to a class of fragments that can form stable reassociation products at $60 \mathrm{C}$ but that are not stable at the more stringent 75 $\mathrm{C}$ criterion. It has been shown that diminished stability is in all probability due exclusively to unpaired bases within the duplexes $(2,3)$.

One should like to correlate $T_{m(e)}$ with percentage of unpaired bases. The best current estimate is that each $1 \mathrm{C}$ degree decrease in stability is due to $1 \%$ unpaired bases within a DNA duplex (20). By using this correlation, decreased thermal stability can be converted to percent divergence (unpaired bases within related portions of DNA). The range of relatedness values and percent divergence between $E$. coli and other representative enteric bacteria is shown in Table 2. Organisms closely related to $E$. coli exhibit as much or very nearly as much binding at $75 \mathrm{C}$ as at $60 \mathrm{C}$. The degree of divergence in these duplexes is usually $3 \%$ or less. In reactions between $E$. coli and less related organisms, there is as much as $17 \%$ divergence within related sequences formed at $60 \mathrm{C}$. The substantial decrease in binding at 75 $\mathrm{C}$ is accompanied by a significant decrease in divergence in the remaining heteroduplexes.

From the data presented thus far we con- clude that: (i) a given percentage of relatedness does not mean that the related sequences consist of stretches of identical nucleotides; (ii) by shifting the incubation temperature, one can select for related sequences that contain varying amounts of unpaired bases; and (iii) by determining the thermal stapbility of DNA heteroduplexes, one can approximate the average amount of divergence or unpaired bases within related DNA.

We assume that enterobacteria evolved from a common ancestor and, therefore, that one can use DNA reassociation to determine how much DNA has diverged to a point where it is no longer related at a given criterion. We use less stringent, but specific, reaction conditions to detect overall relatedness between species. Highly related DNA and specific portions of the genome should be studied at both optimal and more stringent reassociation conditions.

Sensitivity of the method. Hybridization cannot distinguish point mutations or small deletions. Deletions on the order of about $2 \%$ have been identified in at least two cases (3, 12). If one has a selection mechanism, specific genes can be isolated. This has been accomplished for the genes specifying $5 S$ RNA, which comprise only $0.008 \%$ of E. coli DNA (10).

In marginally related organisms, by using total DNA we routinely detect 5 to $10 \%$ relatedness and have detected a $2 \%$ episome (3). If one starts with a specific portion of DNA or RNA, relatedness in $0.004 \%$ or less of the genome can be detected (9). Furthermore, if one desires to assess relatedness between organisms whose overall DNA does not react, one can compare preferentially conserved genes such as those that specify ribosomal RNA, transfer RNA, or $5 S$ RNA $(9,11,22)$.

Taxonomic applications of DNA reassocia-

TABLE 2. Relatedness among enteric bacteria and divergence in related sequences

\begin{tabular}{|c|c|c|c|c|}
\hline \multirow[b]{2}{*}{ Reaction $^{b}$} & \multicolumn{2}{|c|}{ Relative binding $(\%)$ at } & \multicolumn{2}{|c|}{ Divergence $^{a}(\%)$ at } \\
\hline & $60 \mathrm{C}$ & $75 \mathrm{C}$ & $60 \mathrm{C}$ & $75 \mathrm{C}$ \\
\hline Escherichia coli $\mathrm{K}-12 / E$. coli $\mathrm{K}-12$ & 100 & 100 & & \\
\hline E. coli $\mathrm{K}-12 / E$. coli $1485 \ldots \ldots \ldots \ldots$ & 99 & 100 & 0.3 & 0.3 \\
\hline E. coli $\mathrm{K}-12 / E$. coli $04 \ldots \ldots \ldots$ & 85 & 78 & 3.0 & 2.0 \\
\hline E. coli/Shigella dysenteriae. . . & 89 & 85 & 1.5 & 0.5 \\
\hline E. coli/Citrobacter freundii & 50 & 11 & 13.0 & 6.0 \\
\hline E. coli/Salmonella typhimurium & 45 & 11 & 13.5 & 6.0 \\
\hline E. coli/Klebsiella pneumoniae . . & 38 & 7 & 14.0 & 5.0 \\
\hline E. coli/Serratia marcescens .... & 24 & 3 & 14.0 & 5.0 \\
\hline E. coli/Enterobacter hafniae ... & 21 & 4 & 16.0 & \\
\hline E. coli/Proteus mirabilis . . . . . . & 7 & 1 & 17.0 & \\
\hline
\end{tabular}

${ }_{b}^{a}$ Calculated on the basis of $1 \%$ unpaired bases per $1 \mathrm{C}$ degree decrease in duplex stability (20).

${ }^{b}$ Organism on left was source of labeled DNA. 
tion. (i) Identification of mislabeled cultures and of cultures not identifiable by routine means. Some years ago we ordered a culture of Escherichia aurescens from the American Type Culture Collection (ATCC). It was received labeled $E$. aurescens. In the same shipment were a dozen species of Erwinia. Due to haste and stupidity, we assumed that " $E$. aurescens" was also an erwinia. When initial examination showed "E. aurescens" to be virtually indistinguishable from Escherichia coli, we assumed we had a contaminant. When cultures that had been recloned gave identical results, we notified the ATCC that their culture was not "Erwinia" aurescens, but rather Escherichia coli. They informed us that "E. aurescens" was Escherichia aurescens and, in fact, an Escherichia coli strain. After the embarrassment wore off we were happy to realize that the method, in effect, compensated for our taxonomic naivety. We have subsequently tested and successfully classified a dozen cultures that are sufficiently atypical to defy routine biochemical characterization. In addition, we have detected and correctly classified an equal number of mislabeled or misidentified cultures. Any unidentified culture can be placed within an existing group or shown to be significantly different from all existing groups.

A specific example is seen with three so-called atypical species of Erwinia, E. carnegieana, $E$. dissolvens, and $E$. nimipressuralis. These organisms were originally described as pectolytic phytopathogens. In the opinion of most taxonomists, the available Erwinia carnegieana strains are actually strains of Klebsiella pneumoniae, and the available Erwinia dissolvens and Erwinia nimipressuralis strains are actually klebsiellae or Enterobacter cloacae.

We have shown that two of three Erwinia carnegieana strains (EC 186 and EC 223) are most closely related to Erwinia carotovora (Table 3), whereas the third strain (ATCC $13452)$ is probably $K$. pneumoniae. These results were confirmed by $\mathrm{W}$. $\mathrm{H}$. Ewing based on pectinase production and biochemical characterization. In Table 4 are data showing that both Erwinia dissolvens and Erwinia nimipressuralis are more closely related to Enterobacter cloacae than to any other enteric organism including all species of Erwinia.

(ii) Relationships between newly described organisms and existing taxa. Most newly isolated organisms are described largely in terms of their biochemical characteristics. The investigator decides how different an organism is from existing groups and how important these differences are. When the organism obviously belongs in an existing family but is sufficiently different from the known members of the family, it is reported as belonging to a new genus, a new species within an existing genus, or a new biotype of an existing species.

In our opinion DNA-relatedness experiments should be carried out before any group of organisms is recognized as "new." We have examined many newly described enterobacteriaceae for intragroup relatedness as well as relatedness to existing genera. Two examples of

TABLE 4. Relatedness of Erwinia nimipressuralis and Erwinia dissolvens to other Enterobacteriaceae

\begin{tabular}{l|c|c}
\hline \multirow{2}{*}{$\begin{array}{c}\text { Source of labeled } \\
\text { DNA }\end{array}$} & $\begin{array}{c}\text { Relative binding } \\
\text { at } 60 \mathrm{C}(\%)\end{array}$ \\
\cline { 2 - 3 } & $\begin{array}{c}\text { Erwinia nimi- } \\
\text { pressuralis }\end{array}$ & $\begin{array}{c}\text { Erwinia } \\
\text { dissolvens }\end{array}$ \\
\hline $\begin{array}{l}\text { Serratia marcescens ... } \\
\text { Enterobacter cloacae }\end{array}$ & 34 & 34 \\
$\begin{array}{l}\text { 1347-71 } \\
\text { E. cloacae 1523-71 .... }\end{array}$ & 59 & 69 \\
E. cloacae 2740-72 .... & 53 & 73 \\
Erwinia carotovora .... & 34 & 61 \\
Erwinia cypripedii .... & 30 & 32 \\
Erwinia carnegieana ... & 33 & 33 \\
Klebsiella pneumoniae & & 34 \\
\hline
\end{tabular}

TABLE 3. Relatedness of Erwinia carnegieana to other enterobacteriaceae

\begin{tabular}{|c|c|c|}
\hline Reaction $^{a}$ & $\begin{array}{c}\text { Relative } \\
\text { binding } \\
\text { at } 60 \mathrm{C}(\%)\end{array}$ & $\begin{array}{l}\text { Divergence } \\
\text { at } 60 \mathrm{C}(\%)\end{array}$ \\
\hline Erwinia carnegieana EC $186 / E$. carnegieana EC $223 \ldots \ldots \ldots \ldots$ & 99 & 0.2 \\
\hline E. carnegieana EC $186 / E$. carnegieana $13452 \ldots \ldots \ldots \ldots$ & 34 & 15.3 \\
\hline E. carnegieana EC $186 /$ strains of Erwinia carotovora & $57-71$ & $11-12$ \\
\hline E. carnegieana EC 186/strains of Erwinia amylovora. & $24-31$ & $16-18$ \\
\hline E. carnegieana EC $186 /$ Klebsiella pneumoniae . . . . . & 34 & 17.5 \\
\hline E. carnegieana EC $186 /$ strains of Enterobacter cloacae . . . . . . . . & $31-32$ & 18 \\
\hline
\end{tabular}

${ }^{a}$ Organism on left (E. carnegieana EC 186) was source of labeled DNA. 
these studies are given below. In one case, some 20 Edwardsiella tarda strains were studied (D. J. Brenner, G. R. Fanning, A. G. Steigerwalt, and G. V. Miklos. Bacteriol. Proc. 73:42, 1973). These strains are all very closely interrelated and only distantly related to representatives of all other Enterobacteriaceae genera (Table 5). Ewing has placed all of these organisms in a new tribe, Edwardsielleae, with one genus, Edwardsiella, and one species, E. tarda. Our results strongly support these designations. In the other case, Le Clerc and Buttiaux (15) described strains, isolated during the course of an epidemic, which were given a preliminary designation as lysine-positive strains of Citrobacter freundii. We obtained five of these strains from Ewing. They share at least $90 \%$ of their DNA. These strains exhibit some $55 \%$ relatedness to Serratia marcescens and 30\% or less relatedness to all other enteric groups, including $C$. freundii.

(iii) Reference system for identification of clinical isolates. Those who use DNA reassociation are often asked whether the system can be used routinely for clinical purposes. The answer was always "no" because of the time involved and technical considerations. Among the Enterobacteriaceae, we can identify any organism thus far tested as to genus, and almost every organism as to species, solely on the basis of DNA hybridization. It now takes us 7 to 10 days to carefully characterize an organism. We have modified our system to a point where most identifications can be completed within 48 to $72 \mathrm{~h}$. It is hoped that this system will be applicable for use in many clinical laboratories as a reference identification system.

(iv) Use of DNA reassociation in existing taxa. We have determined relatedness within most groups of the family Enterobacteriaceae. Such studies assess the degree of divergence present within a given genus or species. In most cases, relatedness between strains of a given species is $70 \%$ or greater, and $3 \%$ or fewer unpaired bases are present within related sequences. There are some genera where species are extensively diverged and other genera where species are all highly interrelated. A survey of the various levels of relatedness present in equally ranked taxa will help to point out the problems in both biochemical and nucleic acid taxonomic schemes. A summary of such data is presented in Table 6.

As stated above, strains of Edwardsiella tarda constitute a tightly knit group. E. tarda is the sole species in the only genus of the tribe Edwardsielleae. Thus, there is no controversy over this tribe.
TABLE 5. DNA relatedness of Edwardsiella tarda and other enterobacteriaceae

\begin{tabular}{|c|c|c|}
\hline $\begin{array}{c}\text { Source of unlabeled } \\
\text { DNA }\end{array}$ & $\begin{array}{c}\text { Relative } \\
\text { binding } \\
\text { at } 60 \mathrm{C}(\%)\end{array}$ & $\begin{array}{c}\text { Relative } \\
\text { binding } \\
\text { at } 75 \mathrm{C}(\%)\end{array}$ \\
\hline $\begin{array}{l}\text { Strains of } \ldots \ldots \ldots \\
\quad \text { Edwardsiella tarda }\end{array}$ & $84-96$ & $81-93$ \\
\hline Escherichia coli & 25 & 7 \\
\hline Salmonella typhimurium & 25 & 7 \\
\hline Citrobacter freundii & 22 & 11 \\
\hline Serratia marcescens. & 28 & 11 \\
\hline Enterobacter cloacae & 25 & \\
\hline Enterobacter aerogenes & 26 & 8 \\
\hline Erwinia carotovora ... & 20 & 5 \\
\hline
\end{tabular}

In the tribe Escherichieae, the genus Escherichia contains only one species, $E$. coli. E. coli strains are highly interrelated. The four species of Shigella share almost the same amount of DNA as is conserved between strains of a given species of Shigella. Furthermore, relatedness between $E$. coli and shigellae is very nearly as great as intraspecies relatedness in either genus. Escherichieae is an excellent example of a group of closely related organisms that have been "split" due to their medical importance.

A similar situation exists in the medically important genera Salmonella and Arizona in the tribe Salmonelleae. The three Salmonella species and strains of Arizona are highly interrelated. In contrast, citrobacters exhibit only 45 to $55 \%$ relatedness to salmonellae and arizonae. Moreover, the citrobacters appear to be a diverse group of organisms that show as little as $50 \%$ relatedness.

The remaining tribes, Klebsielleae, Proteeae, and Erwinieae, each contain organisms that have extensively diverged. The species in the medically important genus Klebsiella are very closely related. They exhibit about $55 \%$ relatedness to Enterobacter aerogenes but only 20 to $40 \%$ relatedness to other species of Enterobacter and to species of Serratia. The genus Enterobacter exhibits $50 \%$ or less interspecies relatedness. In fact, Enterobacter aerogenes is more closely related to klebsiellae than to either Enterobacter cloacae or Enterobacter hafniae. Strains of $E$. hafniae exhibit as little as $60 \%$ relatedness, and they exhibit no more than $30 \%$ relatedness to other species. Nonpigmented strains of $E$. cloacae are related at a minimum of $70 \%$; yellow-pigmented strains are at least $80 \%$ interrelated. Relatedness between the pigmented and unpigmented strains is only 35 to $50 \%$, despite the fact that both sets of strains are inseparable on the basis of their biochemical characteristics. Strains of Serratia 
TABLE 6. Survey of relatedness among enterobacteriaceae

\begin{tabular}{|c|c|c|c|}
\hline \multirow[b]{2}{*}{ Organism(s) } & \multicolumn{3}{|c|}{ Relatedness $(\%)$ within } \\
\hline & Species & Genus & Tribe \\
\hline Edwardsiella tarda & $84-96$ & $84-96$ & $84-96$ \\
\hline $\begin{array}{l}\text { Escherichia coli } \\
\text { Shigellae }\end{array}$ & $\begin{array}{l}85-100 \\
83-100\end{array}$ & $\begin{array}{l}85-100 \\
76-97\end{array}$ & $\begin{array}{l}80-89 \\
80-89\end{array}$ \\
\hline Salmonellae ${ }^{a}$ & $93-100$ & $74-95$ & $69-80^{b}, 46-58^{c}$ \\
\hline $\begin{array}{l}\text { Arizonaa }^{b} \\
\text { Citrobacters }^{c}\end{array}$ & $\begin{array}{l}73-93 \\
50-97\end{array}$ & $\begin{array}{l}73-93 \\
49-70\end{array}$ & $\begin{array}{l}72-79^{a}, 52-56^{c} \\
46-58^{a}, 52-56^{b}\end{array}$ \\
\hline Klebsiellae $^{d}$ & $86-100$ & $80-90$ & $20-56^{e}, 31-32^{f}$ \\
\hline Enterobacter sp. ${ }^{e}$ & $35-100$ & $24-40$ & $20-56^{d}, 24-36^{f}$ \\
\hline Serratia sp. ${ }^{f}$ & $84-100$ & $47-63$ & $31-32^{d}, 24-36^{e}$ \\
\hline $\begin{array}{l}\text { Proteus sp. } \\
\text { Providenciae }\end{array}$ & & $6-92^{g}$ & $\begin{array}{l}16^{g} \\
16^{g}\end{array}$ \\
\hline Erwiniae & $85-100$ & $15-55$ & $15-56$ \\
\hline Pectobacteria & $80-100$ & $21-69$ & $15-56$ \\
\hline
\end{tabular}

a-f The letters represent the specific genus where there are more than twogenera in a tribe. For instance, "a" represents Salmonella, "b" represents Arizona, and "c" represents Citrobacter. Therefore, the two se relatedness values for salmonellae at the tribe level are: 69 to $80 \%$ with arizonae and 46 to $58 \%$ with citrobacters.

${ }^{g}$ Only one to three pairs of organisms were tested.

are highly related, and species interrelatedness in the genus Serratia is usually 50 to $60 \%$. Serratiae share $35 \%$ or less DNA with members of the genera Klebsiella and Enterobacter.

The Proteeae have not been carefully studied. It is, however, clear from $\mathrm{G}+\mathrm{C}$ differences that the genus Proteus contains widely divergent species. This is borne out by the fact that Proteus mirabilis exhibits 6 to $92 \%$ relatedness with other species of Proteus. In the only reaction carried out, a species of Providencia and Proteus mirabilis were $16 \%$ related.

The tribe Erwinieae, which contains phytopathogens, has two genera, Erwinia and Pectobacterium. In all of these organisms, intraspecies relatedness is quite high: at least $80 \%$. There is extensive divergence present between species; 15 to $55 \%$ relatedness in erwiniae, and 20 to $70 \%$ relatedness in pectobacteria. Relatedness between the genera is at approximately the same level as that seen between species of either genus. In fact, some pectobacteria are somewhat more closely related to erwiniae than to other pectobacteria, and vice versa.

Interpretation of DNA-relatedness data and their application to taxonomy. An ideal taxonomic scheme is one that reflects genotypic as well as phenotypic relatedness and, at the same time, is equally useful for the basic researcher, the clinician, and the taxonomist. For a variety of reasons, this type of universal taxonomic scheme is virtually impossible. One reason is that many taxonomic schemes were drawn up before comprehensive biochemical tests and procedures for assessing molecular relatedness became available. Furthermore, in many cases these schemes were constructed to suit special needs. In some groups, very closely related organisms were placed in different species or even in separate genera. Examples of this trend are Escherichia, Shigella, and Klebsiella. In other genera, such as Erwinia and Pectobacterium, an extremely diverse group of organisms has been brought together because of a single characteristic, which in this instance is phytopathogenicity. The trend seems to have been to "split" medically important organisms and to "lump" nonpathogens.

When one adds to these historic precedents the notorious disagreements between taxonomists in different countries, the picture becomes more clouded. Now the molecular taxonomist has burst upon the scene. Unfortunately, he has often added to the confusion. This seminar represents the first attempt to define the problems and to arrive at some guidelines in interpreting hybridization data for taxonomic purposes.

Many of us have listened to papers at these 
meetings where hybridization was used to "prove" whatever the investigator desired. One investigator deems organisms exhibiting 70 to $80 \%$ reaction to be substantially unrelated, whereas another uses $15 \%$ reaction to affirm close relatedness. We have developed certain guidelines in our studies on the enteric organisms. Although they are not universally applicable, they should at least serve to focus upon the difficulties one encounters and provide a basis for further discussion.

One can attempt to create a new taxonomic scheme based almost completely on DNA relatedness. In principle this is an attractive idea, especially to those of us who specialize in determining DNA relatedness. Such a scheme provides an evolutionary insight into the pathways of bacterial divergence. It also is based on the entire genetic capacity of organisms, in contrast to all other schemes which use a relatively small amount of phenotypic characteristics to distinguish between organisms. Finally, a genotypic scheme does not subjectively weight a character and therefore has the advantage of complete objectivity. The genes are naturally weighted, presumably by evolutionary pressures which allow or inhibit their divergence.

In practice, however, a taxonomic scheme is useful only if it enables a worker to distinguish between organisms. Quite naturally, the industrial microbiologist, the clinical microbiologist, and the phytopathologist rely upon different parameters to select and differentiate between organisms. It is a fact of life that the acceptance of a taxonomic scheme is dependent upon its utility and practicality in a given application. We should, therefore, first consider those applications of hybridization that least conflict with traditional schemes.

(i) Recognition of new taxa. The establishment of new taxa should include a consideration of hybridization data. Pursuant to Recommendation $30 \mathrm{~b}$ of the proposed revision of the International Code of Nomenclature of Bacteria (15), I propose that nucleic-acid relatedness data should be included in the minimal standards required in the descriptions of new taxa of bacteria. These data should be sufficient to show both the interrelatedness between strains placed in a new taxon and the degree of relatedness between the new taxon and all pertinent existing taxa.

(ii) Identification of grossly atypical strains in a taxon. The most atypical strains in a taxon rarely differ from a typical strain in more than a dozen characteristics. When one considers that a bacterium contains sufficient DNA to specify some 3,000 average-size genes, the risk of misidentification of atypical strains is evident.

(iii) Classification of poorly studied groups. Of course, to call a group of organisms "poorly studied" is an arbitrary decision. However, most of us can agree, I am sure, that the enterics are a well-studied group compared with the obligate anaerobes, for example. Hybridization can and should be used in the determination of the taxonomic status of incompletely studied groups. The genetic relationships of such organisms will serve to establish a solid basis for subsequent classification based on phenetic characteristics as well as on DNA relatedness.

(iv) Changes in existing classifications. Any recommendation for a change in taxonomy should include appropriate hybridization data. In fact, I feel that this information should be required before a taxonomic proposal is adopted in a taxonomic compendium such as Bergey's Manual of Determinative Bacteriology. The inclusion of such data will lend genetic support to the phenetic characterization and, in many cases, will diminish the amount of subjectivity involved in taxonomic decisions.

In the examples cited above, I do not mean to imply that investigators should be forced to carry out hybridization experiments or be forced to submit their cultures to one who would perform hybridization experiments. I suggest, rather, that final adoption of taxonomic recommendations be withheld in the absence of corroborative hybridization data. I further suggest the establishment of one or more clearing houses for the determination of nucleic-acid relatedness among the bacteria. Examples of ideal sites for these centers are the American Type Culture Collection and the Center for Disease Control. Finally, I suggest the inclusion of a hybridizationist, either as a full member or as a consultant, on each of the taxonomic subcommittees of the American Society for Microbiology.

Having laid myself open to the scorn of many of my colleagues, I must strongly state that, at least with the enteric bacteria, the taxonomist has, in general, compiled what appears to be an extremely accurate classification. Moreover, he accomplished this long before anyone knew of molecular biology or nucleic-acid relatedness. My point is that the newer techniques open a new vista to taxonomy and that they can and should be used to supplement the conventional techniques.

Having commented on the "less controversial" applications of DNA hybridization, we should turn to the application and interpretation of DNA-relatedness data in the more 
controversial area of biochemically well-defined taxa. Strains of a given species usually exhibit $70 \%$ or greater nucleotide-sequence relatedness. The related sequences contain $8 \%$ or fewer unpaired bases (usually less than $3 \%$ ). These are minimal values with most species showing even higher interstrain relatedness. We believe that the high level of relatedness present among strains of enteric species can be utilized to form a molecular description or definition of most, if not all, species. We have encountered only one apparent gross exception to this rule. This is the low level of relatedness present between pigmented and unpigmented strains of Enterobacter cloacae. It is obvious that two "genetic" species of $E$. cloacae are present. In this case one can designate a second species without creating confusion, as all strains thus far studied are easily distinguished by the presence or absence of pigment.

We cannot affix a definitive level of relatedness at the genus or tribe level. The rule we try to follow is that a member of a given genus should exhibit a greater level of relatedness to other species in that genus than to members of any other genus. The same rationale is followed at the level of tribe. Following these rules, we have advocated or supported the reclassification of several organisms.

There are many cases where a strict interpretation of hybridization data, in the absence of other considerations, will result in taxonomic changes. We tend to avoid proposing changes where current classification is both functional and essentially correct. For instance, the level of relatedness between shigellae and Escherichia coli is sufficient to logically place these organisms in the same genus as separate species. It is also arguable as to whether species of Shigella or Klebsiella have diverged sufficiently to merit species status, but the fact is that these organisms will continue to be differentiated because it is practical to do so in the clinical laboratory.

Two other examples are found in Salmonelleae. The three species of Salmonella cannot be distinguished by DNA relatedness. Here again the differentiation of salmonellae is a relatively simple laboratory procedure and is important for clinical and epidemiological purposes. By contrast, arizonae form two highly related, but separable, groups based on rapidity of lactose fermentation, antigenic patterns, and DNA relatedness. Only a few laboratories in the world are equipped to differentiate between various arizonae, and this differentiation will not be made regardless of whether the groups are nomenclaturally separated. The groups cited in these examples are obviously well classified. The question is whether they should remain arbitrarily speciated due to medical considerations as at present or whether they should be altered because of DNA relatedness. At this time we feel that they should remain unchanged for two reasons. First, the present classification is well understood and useful, and second, it is not grossly contradictory to any rules for molecular taxonomy that can be set down at present. Of course, taxonomy is a dynamic field, and it should be reviewed continually as new data are amassed.

A final example illustrates an area in which changes in classification recommended from hybridization data add accuracy as well as practicality. Klebsiella pneumoniae and Enterobacter aerogenes, until quite recently, were a source of confusion both in the clinical laboratory and for the taxonomist. All too often these organisms were classified on the basis of the site of isolation or solely on motility. Our data showed that both motile and nonmotile $E$. aerogenes are very highly related to each other and that strains of both types are easily distinguishable from $K$. pneumoniae (50 to $60 \%$ relatedness). Organisms that have diverged to this extent should be easily distinguishable if the correct biochemical tests are used. In this case, the assumption is correct, since the combined use of motility and urease and ornithine decarboxylase production is sufficient to differentiate between $K$. pneumoniae and $E$. aerogenes.

Very few firm proposals are made in this presentation. I tried to delineate problems, raise questions, provoke thoughts, and stimulate discussion. It seems appropriate to close by citing some comments we received regarding one of our recent manuscripts. A clinically oriented colleague wrote: “. . . it would appear that you are not ready to talk about practicalities in this paper." One of the reviewers of this manuscript, who obviously was not clinically oriented, felt that we did not make recommendations justified by our data because we were afraid of the clinical microbiologists and the pressure that they would bring to bear.

This, then, is where we presently stand. The rate of progress will be largely determined by the level of concern and the amount of meaningful communication that occurs between all interested parties.

\section{REPRINT REQUESTS}

Address requests for reprints to: Dr. Don $\mathbf{J}$. Brenner, Division of Biochemistry, Walter Reed Army Institute of Research, Washington, D. C. 20012. 


\section{LITERATURE CITED}

1. Bernardi, G. 1965. Chromatography of nucleic acids on hydroxyapatite. Nature (London) 206:779-783.

2. Brenner, D. J., and D. B. Cowie. 1968. Thermal stability of Escherichia coli-Salmonella typhimurium deoxyribonucleic acid duplexes. J. Bacteriol. 95:2258-2262.

3. Brenner, D. J., and S. Falkow. 1972. Molecular relationships among members of the Enterobacteriaceae. Advan. Genet. 16:81-117.

4. Brenner, D. J., G. R. Fanning, K. E. Johnson, R. V. Citarella, and S. Falkow. 1969. Polynucleotide sequence relationships among members of the Enterobacteriaceae. J. Bacteriol. 98:637-650.

5. Brenner, D. J., G. R. Fanning, F. J. Skerman, and S. Falkow. 1972. Polynucleotide sequence divergence among strains of Escherichia coli and closely related organisms. J. Bacteriol. 109:953-965.

6. Britten, R. J., and D. E. Kohne. 1966. Nucleotide sequence repetition in DNA. Carnegie Inst. Wash. Year B. 65:78-106.

7. De Ley, J., H. Cattoir, and A. Reynaerts. 1970. The quantitative measurement of DNA hybridization from renaturation rates. Eur. J. Biochem. 12:133-142.

8. Denhardt, D. 1966. A membrane filter technique for the detection of complementary DNA. Biochem. Biophys. Res. Commun. 23:641-646.

9. Doctor, B. P., M. E. Banning, D. J. Brenner, G. R. Fanning, M. J. Fournier, P. S. Handley, W. L. Miller, M. A. Sodd, and A. Steigerwalt. 1972. Isolation, purification and characterization of $5 \mathrm{~s}$ RNA and tRNA cistrons from $E$. coli, p. 11-50. In Cellular processes in growth, development and differentiation. Dept. of Atomic Energy, Bombay, India.

10. Doctor, B. P., and D. J. Brenner. 1972. Isolation of $5 \mathrm{~s}$ ribonucleic acid cistrons and tRNA cistrons from Escherichia coli. Biochem. Biophys. Res. Commun. 46:449-456.

11. Goodman, H. M., and A. Rich. 1962. Formation of a DNA-soluble RNA hybrid and its relation to the origin, evolution and degeneracy of a soluble RNA. Proc. Nat. Acad. Sci. U.S.A. 48:2101-2109.

12. Hoyer, B. H., and N. B. McCullough. 1968. Homologies of deoxyribonucleic acids from $\mathrm{Bru}$ cella ovis, canine abortion organisms, and other Brucella species. J. Bacteriol. 96:1783-1790.

13. Johnson, J. L., and E. J. Ordal. 1968. Deoxyribonucleic acid homology in bacterial taxonomy: effect of incubation temperature on reaction specificity. J. Bacteriol. 95:893-900.

14. Lapage, S. P., W. A. Clark, E. F. Lessel, H. P. R. Seeliger, and P. H. A. Sneath. 1973. Proposed revision of the International Code of Nomenclature of Bacteria. Int. J. Syst. Bacteriol. 23:83-108.

15. Le Clerc, H., and R. Buttiaux. 1965. Les Citrobacter. Ann. Inst. Pasteur 16:67-74.

16. Marmur, J., and P. Doty. 1961. Thermal renaturation of DNA. J. Mol. Biol. 3:585-594.

17. Marmur, J., and P. Doty. 1962. Determination of the base composition of deoxyribonucleic acid from its thermal denaturation point. J. Mol. Biol. 5:109-118.

18. Marmur, J., R. Rownd, and C. L. Schildkraut. 1963. Denaturation and renaturation of DNA. Progr. Nucl. Acid Res. Mol. Biol. 1:231-300.

19. McCarthy, B. J. 1967. Arrangement of base sequences in deoxyribonucleic acid. Bacteriol. Rev. 31:215-229.

20. McConaughy, B. L., and B. J. MeCarthy. 1970. Related base sequences in the DNA of simple and complex organisms. VI. The extent of base sequence divergence among the DNAs of various rodents. Biochem. Genet. 4:425 446 .

21. Miyazawa, Y., and C. Thomas. 1965. Composition of short segments of DNA molecules. J. Mol. Biol. $11: 223-237$.

22. Moore, R. L., and B. J. McCarthy. 1967. Comparative study of ribosomal ribonucleic acid cistrons in enterobacteria and myxobacteria. J. Bacteriol. 94:1066-1074.

23. Seidler, R. J., and M. Mandel. 1971. Quantitative aspects of DNA renaturation: base composition, state of chromosome replication, and polynucleotide homologies. J. Bacteriol. 106:608-614. 